\title{
Development of Copeland Score Methods for Determine Group Decisions
}

\author{
Ermatita $^{* 1}$ \\ Department of Information System, \\ Computer Science Faculty of Sriwijaya University \\ Indonesia \\ Jl. Palembang-Prabumulih, Ogan Ilir, INDONESIA
}

\author{
Sri Hartati ${ }^{* 2}$, Retantyo Wardoyo ${ }^{* 2}$, Agus Harjoko ${ }^{* 2}$ \\ Departement of Computer Science and Electronics \\ Faculty of Mathematics and Natural Sciences \\ Gadjah Mada University, Indonesia
}

\begin{abstract}
Voting method requires to determine group decision of decision by each decision maker in group. Determination of decisions by group of decision maker requires voting methods. Copeland score is one of voting method that has been developed by previous researchers. This method does not accommodate the weight of the expertise and interests of each decision maker. This paper proposed the voting method using Copeland score with added weighting. The method has developed of considering the weight of the expertise and interests of the decision maker. The method accordance with the problems encountered of group decision making . Expertise and interests of decision makers are given weight based on their expertises of decision maker contribution of the problems faced by the group to determine the decision.
\end{abstract}

Keywords—Group Decision Support System; Copeland Score.

\section{INTRODUCTION}

Decision making is the selection process of various alternative actions that might be chosen through a specific mechanism to make the best decision. The decision maker is done in order to achieve certain goals or objectives for solving problems.

Organizational leaders rarely can solve the problem alone. Committees, working teams, project teams and task forces were formed in many organizations is approach to problem solving by group. GDSS is a computer-based interactive system to facilitate the achievement solution of problem by a group of decision makers. That is consistent with the statement of Turban (2005): A group decision support system (GDSS) is as interactive components of the facilities based system that solution of semi structured or unstructured problems by a group of decision makers in unstructured nature. GDSS was developed to address challenges to the quality and effectiveness of decision-making is done by more than one person (group of people). Issues that need to be highlighted in decision-making by a group of people, among others, is the number of decision-makers, the time should be allocated, and the increase the existing participants. GDSS provides support in solving the problem by providing a setting that supports communication for members who joined the group. The problem solving is done by a group of people who are members of the GDSS who need a voting method to obtain a group decision. Copeland score method is one method of voting to earn wages, which is a joint decision-making. So far, existing methods Copeland score considers that all of the decision maker has the same weight, but sometimes the decision maker has a different weight in determining a joint decision. For it is necessary to develop a method of voting with respect to the weight of each decision maker based on the level of expertise and interests to the problem.

\section{BACKGROUND THEORIES}

\section{A. GROUP DECISION SUPPORT SYSTEM (GDSS)}

GROUP DECISION SUPPORT SYSTEM (GDSS) is an interactive computer based system that facilitates solution of some unstructured problems by a few (sets) of decision makers who work together as a group. GDSS can be applied to different groups of decision situations, which includes a review panel, task force executive meeting / board, remote workers, and so forth. The basic activities that occurred in any group who require support on a computer are:

1) Calling information, involving the selection of data values from an existing database or calling simple information.

2) Information sharing, meaning the viewer displays the data on the screen to be viewed by groups.

3) Use of information, including application software technology, procedure, and group problem solving techniques to the data. [8]

\section{B. COPELAND SCORE BY WEIGHTING}

Copeland score is one of the voting methods with a technique based on the reduction of the victory frequency with the defeat frequency by pair wise comparisons [1]. Examples of the determination of the method of paired comparisons copeland score can be seen in Figure 1.

\begin{tabular}{|c|c|c|c|}
\hline Population & Preferences & Contest & Winner \\
\hline $45 \%$ & $a d b c$ & a vs. b & $\mathrm{b}$ \\
\hline $40 \%$ & b a d c & a vs. c & a \\
\hline $15 \%$ & $c \quad b \quad a d$ & a vs. $d$ & $a$ \\
\hline \multicolumn{2}{|c|}{ Preference profiles } & $\begin{array}{l}\text { b vs. c } \\
\text { b vs. } d \\
\text { c vs. d }\end{array}$ & $\begin{array}{l}b \\
b \\
d\end{array}$ \\
\hline
\end{tabular}

\begin{tabular}{|c|c|}
\hline Alternative & Copeland score \\
\hline $\mathrm{a}$ & $2-1=1$ \\
$\mathrm{~b}$ & $3-0=3$ \\
$\mathrm{c}$ & $0-3=-3$ \\
$\mathrm{~d}$ & $1-2=-1$ \\
\hline
\end{tabular}

Voting Results

Pair-wise contests

Fig.1. Determination of the method of paired comparisons Copeland Score [1] 
Many reseachers studied used the Copeland Score method to problem solving in group decision maker. Research about the Copeland score method by [Faliszewski et al. (20080] who use the electoral system Myhstic Ramon Llull and Copeland Election System. This method can be used to comprehensively control the electoral system. In addition, this study also shows that the integration of Llull and Copeland Voting preferences could overcome the irrationality of potential voters.

Furthermore, [Saari and Merlin (1994) ]have been developed Copeland Method (CM) with Geometry approach. The study compared the relationship between Copeland Method (CM) and Positional Voting Methods. CM ranking is done in many ways that vary from voting in the election of the electoral system. The results show how the new CM has powerfull to vote.

Another research conducted by [Al-Sharrah (2010)] who performed a number of objects with the Copeland ranking Score. The study was conducted to rank objects (chemicals, projects, databases, etc.) when the number of available indicators provide different information. The results showed that the Copeland method was an effective and stable tool for ranking objects. The Copeland Score method has the advantage to facilitate the analysis of partial large collection of objects.

The Copeland Score method based on Weighting Score voting process is needed to determine which decisions can be recommended. Decision results of alternative ranking by each decision maker, must be processed to determine the decisions recommended by the group. To select an alternative decisionmaking group has been established from a variety of skills performed by using the method of Copeland Score [1] as a group decision. The results of each decision maker will be processed with voting by the Copeland Score method suppose the decision of each expert as the sequence shown in Table 1. It is assumed that there are three options, namely $A_{1}, A_{2}$, and $\mathrm{A}_{3}$. The process of copeland score method, all of the population who choose $A_{1}, A_{2}$, and $A_{3}$ in accordance with the table of preference profiles. Pair wise contests table shows that one option $\left(\mathrm{e} / \mathrm{g} \mathrm{A}_{1}\right)$ compared to the overall choice $\left(\mathrm{A}_{2}, \mathrm{~A}_{3}\right)$. This pair wise comparison is done one by one and imposed on the overall participant choice. Pair wise comparisons between A1 to A2 so much to choose A1, A1 pair wise comparisons were selected A1 to A3. It turns out the pair wise contests of the table shows that A1 is chosen twice. The alternative A2 option does not appear whereas alternative A3 options appears once.

The table 2 it can be shown A1 has a winning choice as much as twice to A1 and A2, and defeat one time to A2 based on the pair wise contests. To determine whether choice of Alternative A3 is the best option or not, then do the subtraction operation frequency with the frequency of wins versus defeat. We can see at Table 1 voting results showed that the choice of A1 has the highest frequency. Based on the frequency, then the alternative voting A1 was selected as the winner.
TABLE I. Result of decision Maker

\begin{tabular}{|c|c|c|c|}
\hline $\begin{array}{c}\text { Decision } \\
\text { Maker }\end{array}$ & \multicolumn{3}{|c|}{ Alternative } \\
\hline P1 & A2 & A1 & A3 \\
\hline P2 & A1 & A3 & A2 \\
\hline P3 & A3 & A1 & A2 \\
\hline
\end{tabular}

The results from each expert then contested in each element, so that the resulting such

TABLE II.

Pairwise Contest

\begin{tabular}{|c|c|c|c|}
\hline \multicolumn{4}{|c|}{ Pairwise Contest } \\
\hline A1 & Vs & A2 & A1 \\
\hline A1 & Vs & A3 & A1 \\
\hline A2 & Vs & A3 & A3 \\
\hline
\end{tabular}

Having obtained the results match the calculated value of copeland score. Copeland score results will be processed by using the weights of each DM and the weight of the place from the Copeland Score. Calculation results is shownTable 3 . The highest score is the winner, in this case a group decision recommendation.

TABLE III. Result of Voting

\begin{tabular}{|c|c|c|c|}
\hline \multicolumn{4}{|c|}{ Copeland score } \\
\hline A1 & $2-0$ & 0 & Winner \\
\hline A2 & $0-2$ & -2 & \\
\hline A3 & $1-1$ & 0 & \\
\hline
\end{tabular}

Voting results showed that the value of Alternative 1 $\left(A_{1}\right)$ has a value of 2 , which is the highest value. $A_{3}$ then the second highest, and the lowest is the $A_{2}$. Winner of the sequences is $A_{1} A_{2} A_{3}$.

This sequence is not yet a final decision, the process is carried out based on the weight given by the DM. The weight refers to the determination of the agreement shows that the highest weight is an expert in the area of expertise that contributed most in decision-making. Suppose the weight of $\mathrm{DM} 1=5, \mathrm{DM} 2$ and DM3 $=3=2$, the value of place based on the highest copeland is based on the amount of data. For example the data above there are 3 places the highest value is given to A1 3, the value of 2 is given to A3 and A2 value is 1 .

Top expert weight multiplied by the value of the place. The multiplication of the weights and the experts will place the weights in the ranking so as to produce the final decision recommendations. By calculations: 


$$
\begin{aligned}
& A_{1}=3 \times 3=9 \\
& A_{3}=2 \times 2=4 \\
& A_{2}=5 \times 1=5
\end{aligned}
$$

Results of Copeland method calculation obtained by weighting the order: A1 A2 A3. This means the winner is alternative A1. The voting result of decision maker group is A1 as the recommendations of the group.

\section{CONCLUDING REMARKS AND FURTHER WORKS}

Shared decision making by some decision maker in a group requires voting methods. Voting method is implemented to accommodate the interests and expertise of the decision maker. To determine the group decision a decision maker requires specific weights of each decision maker. The weight determines how important decision maker with expertise have contributed to decision making. The copeland score method which has been developed by Garvish does not accommodate the weight of each decision maker. This paper developed methods of voting in decision making to accommodate the weights based on the importance of expertise decisionmaker in the decision making process as a solution to the problem /

\section{REFERENCES}

[1] Gavish, B. and Gerdes, J.H., 1997, Voting Mechanisms and Their Implications in A GDSS Environment, Annals of Operations Research Science Publisher.

[2] Al-Sharrahm G., 2010, Ranking Using the Copeland Score: A Comparison with the Hasse Diagram, J. Chem. Inf. Model, 785-791.

[3] Saari, D.G and Merlin, V.R., 1996, The Copeland Method* L: Relationships and the Dictionary, Economic Theory, 51-76.

[4] Faliszewski, P and Hemaspaandra. E, Hemaspaandra. A. L. and Rothe. J., 2008, Copeland Voting Fully Resist Constructive Control, R.Fleisther and J.Xu (eds):AAIM 2008, 165:176.

[5] Turban, E. and Aronson, E.J., 2005, Decision Support Systems and Intelligent Systems 7th-ed. jilid I (Sistem Pendukung Keputusan dan Sistem Cerdas), diterjemahkan oleh Dwi Prabantini, Andi, Yogyakarta.

[6] Turban, E., Sharda, R.. and Delen, D., 2011, Decision Support and Business Iintelligence Systems, ninth Edition, Prentice Hall, new jersey, USA.

[7] E. Turban, "Dicision Support and Expert Systems: Management Support Systems", Fourth Edition, Prentice-Hall,Inc., United State, 2005

[8] Q. Zhang and J. Ma, "Determining Weights of Criteria Based on Multiple Preference Formats", online pada http://www.is.cityu.edu.hk/Research /WorkingPapers/paper/0102.pdf 12 Oktober 2004, 2004 